\title{
Ortodontide 3 Boyutlu Stereofotogrametri
}

\author{
Dimensional Stereophotogrammetry in Orthodontics
}

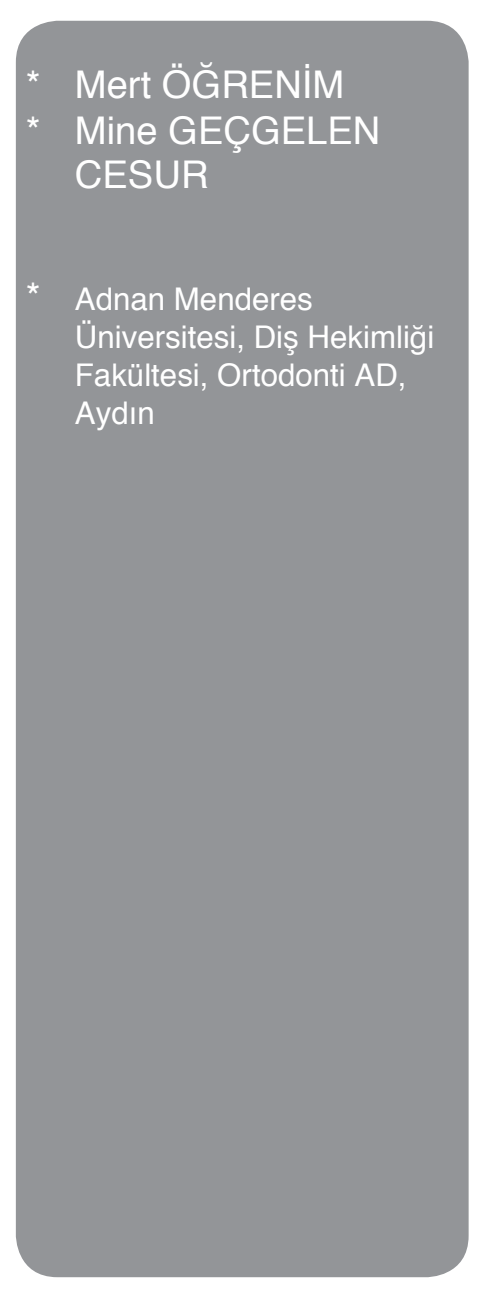

Yazışma Adresi:

Arş. Gör. Dt. Mert Öğrenim Adnan Menderes Üniversitesi Diş

Hekimliği Fakültesi Ortodonti

Anabilim Dalı Eski Tıp Yerleşkesi

No:1 09100 Aydın

Tel No: 05335574776

e-mail: mogrenim@hotmail.com

\section{Öz}

Günümüzde estetik ve güzel görünmenin önemi göz ardı edilemez. Hastaların ortodontik tedaviden beklentileri gibi hekimlerin de tedavi planlamaları öncelikle ideal yüz estetiğini sağlamak üzerinedir. İdeal yüz estetiğinin ne olduğu objektif kurallarla tam olarak açıklanamamıştır. Ancak kuralları kesin olmasa da kompleks bir yapı olduğunu ve yumuşak dokunun fasiyal estetiğin en önemli parçalarından biri olduğu bilinmektedir.

Teknolojik gelişmeler sayesinde yumuşak dokuların 3 boyutlu görüntülerinin elde edilmesi mümkün hale gelmiştir. Stereofotogrametrik sistemler, fasiyal yumuşak dokudan 3 boyutlu görüntü alabilen ve en avantajı özellikler sunan yumuşak doku tarama sistemleridir. Bu sistemler sayesinde yumuşak dokunun ayrıntılı kayıtları hastaya hiçbir zarar vermeden tekrar alınabilmektedir. Ortodontistler, bu kayıtların karşılaştırıması ve üzerinde yapılan ölçümlerle, ortodontik tedavinin hastada nasıl bir değişim gerçekleştirdiğini objektif olarak değerlendirebilmektedir. Özellikle tek başına ortodontik tedavinin yetmediği, ortognatik cerrahi gereksinimi duyulan hastalarda tedavi başlangıcında yumuşak doku hedeflerinin belirlenebilmesi için 3 boyutlu stereofotogrametrik görüntüleme, hekimlere büyük avantaj sağlamaktadır.

3 boyutlu stereofotogrametrik sistemler ile yalnızca yumuşak dokuların taranabilmesi mümkündür. Sert dokuların ve dental kayıtların 3 boyutlu ortama aktarılabilmesi için başka sistemlere intiyaç duyulmaktadır. Fasiyal dokuların gerçek bir modellemesi ancak tüm kayıtların senkronizasyonu ile mümkündür. Gelecekte tek bir sistem ile tüm dokuların kayıtlarının alınabilmesi teknolojik gelişmeler sayesinde beklenen bir durumdur.

Anahtar Kelimeler: Stereofotogrametri, 3D Görüntüleme, Yumuşak Doku, Fasiyal Estetik

\section{Abstract}

Today, the importance of the beatiful appearance and aesthetic can not be ignored. Patients' expectations of orthodontic treatment and treatment planning of orthodontist primarily on providing the ideal facial aesthetics. It is not completely explained by objective rules as to what the ideal facial 
aesthetics. Although there is no definite rules about this topic, it is known that the facial aesthetics is complex composition and soft tissue is one of the most important parts of the facial aesthetics. For this reason, soft tissue should be monitored and recorded at every stage of orthodontic treatment.

With technological developments, it has become possible to obtain three-dimensional images of soft tissues. Stereophotogrammetry systems are most advantageous soft tissue scanning system that can take 3D images of the facial soft tissue. Through this system, detailed records of the soft tissue can be taken repeatedly without any harm to the patient. Orthodontists making measurements on 3-dimensional images obtained from the patient can be evaluated objectively how to performed change on the patients of orthodontic treatment. Especially for orthognathic surgery patients, stereophotogrammetric 3-D imaging is a great advantage to the physician for determine the requested changes to be obtained in soft tissue at the treatment planning.

3D stereophotogrammetric systems can scan only soft tissue. 3D scanning of hard tissue and dental records are needed to other systems. For a real modeling of facial tissue only possible with synchronization of all records. With the development of technology at the future, it will be able to records of all facial tissue with a single system.

Keywords: Stereophotogrammetry, 3D Imaging, Soft Tissue, Facial Aesthetic

\section{Giriş}

Günümüzde dıș görünüşün hayatın her alanında büyük bir etkiye sahip olduğu herkesin bildiği bir gerçektir. Dış görünümün de en önemli parçası yüz estetiğidir. Geçmiş dönemlere baktığımızda ortodontik tedavinin asıl amacının dişlerin biyolojik ve fonksiyonel olarak uygun konumda olmasını sağlamak olduğu görüşü hakimdi. Tedaviyi bu hedeflere göre yaptığımızda estetiğin de sağlanacağı düşünülmekteydi. Ancak son yıllarda ortodontik tedavi açısından da estetiğin önemi anlaşılmış ve tedavi planlamasında fonksiyon ve biyolojiden önce, estetiğin öncelikli hedef olduğu belirtilmiştir $(1,2)$. Hastada malokluzyon görülmesinin bir anomaliye işaret ettiğini ancak tedavi planlamasının yumuşak dokuya göre şekillenmesi gerektiği belirtilmiştir (3).

Başlangıç tedavi planlamasının, ara safha ve tedavi sonucu değerlendirmelerinin doğru bir şekilde yapılabilmesi için, yumuşak doku kayıt ve analizlerinin objektif, güvenilir ve tekrarlanabilir olmasına intiyaç vardır (4). Bu nedenler sonucunda 3 boyutlu yumuşak doku tarama sistemleri ortaya çıkmıştır.

\section{Ortodontik Açıdan Yumuşak Doku ve Yüz Estetiği}

Fasiyal estetik, tüm kültürlerde yüzyıllar boyunca insanları yakından ilgilendiren bir konu olmuştur. Yapılan araştırmalarda, ideal yüz estetiğine sahip ya da toplum tarafından "güzel" veya "yakışıklı" kabul edilen kişilerin sosyal yaşam ve hayatın birçok alanında daha avantajlı oldukları, bu kişilerin daha mutlu ve başarılı bir hayata sahip oldukları, toplum tarafından daha pozitif yaklaşıldığı bulunmuştur. Fasiyal estetiğin iş hayatında kolaylık sağladığı, insanların ilgisini çekmeyi kolaylaştırdığı da yapılan çalışmalarda belirtilmiştir (5-8).

$\mathrm{Bu}$ değerlendirmeler, çalışmalar sonucunda elde edilmiş olsa da çağımızda tüm insanlar güzel olmanın hayatı kolaylaştıran bir özellik olduğunu bilmektedirler. Bu sebeple hem hastaların hem de hekimlerin fasiyal estetiğe olan ilgisi artmış ve ortodontik veya ortognatik tedavi sonucunda ideal yüz estetiğine ulaşmak herkesin amacı olmuştur (9). Ortodontik tedavinin de temel hedefleri fasiyal estetik ve fonksiyonel okluzyon olarak tanımlanmıştır (10).

\section{Ortodontide Yumuşak Doku Değerlendirmesi}

Ortodontistler uzun yıllardır yumuşak doku ve fasiyal estetiğin önemini bilmekte ve bu konuda ölçümler, analizler, normlar geliştirerek tedavi planlamalarıyla ilgili bilgiler edinmekte ve tedavi sonucu öngörüleri belirlemektedirler. Direkt antropometri, 2 boyutlu fotogrametri, lateral sefalometrik radyografiler ve anteroposterior radyografilerle yapılan yumuşak doku analizleri günümüzde halen kullanılan yöntemlerdir (11-17). Bu konudaki en eski yöntem kumpasla yapılan 
antropolojik direkt ölçümlerdir ve genellikle diğer yöntemlerin güvenirliliğinin araştırıldığı çalışmalarda direkt ölçümler altın standart kabul edilir (18).

2 boyutlu görüntüler (sefalometrik radyografiler, antero-posterior radyografiler, fotoğraflar vs.) ise çok fazla hasta kooperasyonu gerektirmez ve arşivlenmesi kolaydır. Ayrıca dönem dönem tekrarlanabilirliği, kolay uygulanması ve ucuz olması da bu yöntemlerin avantajlarındandır. Günümüz teknolojisiyle sefalometrik ve antero-posterior radyografi çekimleri için düşük doz radyasyon uygulanıyor olsa da, bu yöntemler de invaziv olarak kabul edilir. Yüzey morfolojisi ile ilgili detaylı bilgilerin de bu yöntemlerle alınması mümkün değildir. Anatomik noktalar belirlenememektedir ve dokuların derinlik ölçümleri yapılamamaktadır (19).

Bu durum 3 boyutlu görüntüleme ihtiyacının ortaya çıkış noktasıdır. İlerleyen dönemlerde teknolojinin tıp alanında da kendini göstermesiyle 3 boyutlu görüntüleme sistemleri ortaya çıkmış, bilgisayarl tomografi (BT), konik ışınlı bilgisayarlı tomografi (KIBT), manyetik rezonans görüntüleme (MRG) gibi sistemler yumuşak dokuların 3 boyutlu görüntülenmesine olanak sağlamışlardır $(20,21)$.

BT ve KIBT yumuşak dokuların 3 boyutlu görüntülenebilmesini sağlar ancak bu cihazların pahalı olması, hastaya iyonize radyasyon uygulanması, tüm kliniklerde bulunamaması, hastanın tarama sırasında hareket etmesi, metal dolgu veya braketler sebebiyle artefaktlar oluşması, radyasyon sebebiyle sık aralıklarla tekrarlanamaması ve 3 boyutlu yüzey tarama cihazları kadar iyi morfolojik bilgiler vermemesi (cilt rengi ve yüzey morfolojisi) gibi dezavantajları bulunmaktadır $(22,23)$.

MRG sistemlerinin en büyük avantajı radyasyon kullanmadan yumuşak doku görüntülemede ayrıntılı bilgiler vermesidir. Ancak pahalı ve gelişmiş ekipmanlar olması, dental kliniklerde rutin kullanılan cihazlardan olmaması, cilt ile ilgili renk ve morfolojik bilgiler vermemesi, klostrofobisi olan hastalar için sorun teşkil etmesi, görüntü elde edilmesinin uzun sürmesi gibi dezavantajları bulunmaktadır $(24,25)$.
3 boyutlu ultrasonografi sistemlerinin KIBT sistemlerine göre düşük maliyete sahip olması ve radyasyon kullanmaması gibi avantajları vardır. Tarama süresinin uzun olması, dental klinikler için rutin kullanılan bir sistem olmaması, cilt yüzeyiyle ilgili bilgi verememesi, yumuşak doku kontakt noktalarında görüntüde bozulmalar ortaya çıkması bu sistemlerin dezavantajlarıdır $(26,27)$.

Yumuşak doku yüzey taraması için3 boyutlu stereofotogrametri, likit kristal uzaklık ölçüm, 3 boyutlu lazerli yüzey tarama, yapısal ışıklandırma tekniği, moire topografi gibi sistemler çeşitli dönemlerde kullanılarak yumuşak dokunun 3 boyutlu görüntüleri elde edilmiştir. Bu sistemlerden günümüzde kullanılanlar lazer tabanlı 3 boyutlu tarama sistemleri ve optik tabanlı tarama sistemlerinden olan yapısal ışıklandırma ve 3 boyutlu sterefotogrametridir. Dünya çapında son dönemde en yaygın kullanılan sistem ise 3 boyutlu sterefotogrametri sistemleridir (28).

\section{Stereofotogrametri Nedir}

Stereofotogrametri, 3 boyutlu bir cismin aynı düzlem üzerinde farklı açılardan elde edilen görüntülerini kullanarak 3 boyutlu görüntü elde etme yöntemidir. Bu tekniğin temeli tüm canlılarda var olan steroskopik görüş prensibine dayanmaktadır. Görüntüde derinlik algısını oluşturabilmek için beyin, farklı açılardan görüntü alan 2 gözden gelen görüntüleri kullanır. Gözlerin aynı düzlemde bulunması ve farklı açılardan görüntü alması, 3 boyutlu algıyı oluşturur. Nesneden eşit uzaklıkta, aynı düzlem üzerinde ve kalibre edilmiş en az 2 kamera ile elde edilen görüntülerin rekonstrükte edilmesiyle nesnenin 3 boyutlu görüntüsü elde edilmektedir (28-30).

Klinik açıdan değerlendirildiğinde özellikle yumuşak doku morfolojisinin incelenebilmesi için stereofotogrametri, günümüz teknolojisi çerçevesinde en ideal yöntem olarak gösterilmiştir. Geliştirilen sistemler sayesinde vücudun tamamı veya spesifik bir bölgesinin 3 boyutlu görüntüsünü çok kısa bir sürede elde etmek mümkündür (30-32). 


\section{Stereofotogrametrinin Tarihsel Gelişimi}

Sterefotogrametri, stereos (katı), photos (ışık), grama (çizim), metron (ölçme) kelimelerinin birleştirilmesiyle türetülmiştir. Medikal alanda bilenen ilk kullanımı Dr. Holmes tarafından Amerikan iç savaşı sebebiyle bacaklarını kaybeden askerlere protez bacak tasarımı için kullanılmıştır. Fotogrametri üzerinde analizle ilgili ilk yayın ise 1899 yılında Finsterawlder tarafından yapılmıştır (30). Thalmaan tarafından stereofotogrametrinin kliniklerde ilk kullanım denemesi yapılmıștır (33). Burke ve Beard, Thalmaan'ın yöntemini geliștirerek daha basit ve ucuz kameralar kullanmışlardır. Çok katlı grafik sistemi kullanarak daha kısa sürede daha gelişmiş görüntüler elde etmeye çalışmışlardır. Geliştirdikleri sistemi fasiyal deformiteleri olan çocukları (dudak damak yarıklı hastalar vs.) değerlendirmek ve büyüme çağındaki çocuklardaki tedavi öncesi ve sonrasındaki yumuşak doku değişimlerini ölçebilmek için kullanmışlardır (34).

Ras ve arkadaşları yaptıkları çalışma sonucunda fasiyal morfolojideki gelişim ve değişimleri belirlemek için stereofotogrametrinin güvenilir bir 3 boyutlu kayıt yöntemi olduğunu söylemişlerdir (29). Deacon ve arkadaşları bu tekniği büyük oranda geliştirmişlerdir. Kayıt alımı için önceden kalibre edilmiş kameralar ve CCD sensörleri kullanmışlardır. Bu şekilde dijital ortama aktarılan fotoğraflar üzerinde yazılımlar sayesinde otomatik 3 boyutlu analiz yapılabilmiş ve manuel yöntemlere göre analizin çok daha kısa sürelerde yapılabilmesi sağlanmışıı (35).

\section{Stereofotogrametrinin Klinik Kullanım Alanları}

3 boyutlu stereofotogrametri sistemlerinin çok geniş bir kullanım alanı vardır. Medikal kullanım alanlarına baktığımızda en çok plastik cerrahlar, maksillofasiyal cerrahlar, ortodontistler ve psikiyatristler tarafından tercih edilmektedirler (36-38). Ortodonti özelinde değerlendirdiğimizde ise kullanım amaçları şu şekilde sıralanabilmektedir:

- Ortodontik problem listesi ve tedavi planlaması hazırlığında (39),

- Yaş, cinsiyet ve ırk özelliklerine göre yumuşak doku farklııklarının karşılaştıııması $(40,41)$,

- Büyüme ve gelişimin incelenmesi, dönemsel takibin yapılması $(18,42)$,

- Fasiyel estetiğin değerlendirilmesi (43),

- Yüz tipi ve fasiyal oranların değerlendirilmesi $(43,44)$,

- Gülümseme estetiği ve gülümseme tiplerinin değerlendirilmesi (43)

- Ortodontik tedavi öncesi ve sonrası alınan görüntülerin çakıştırılarak değerlendirilmesi $(45,46)$,

- Hastanın 3 boyutlu görüntülerinin dijital olarak arşivlenmesi $(45,46)$,

- Kraniyofasiyal sendromların incelenmesi (47),

- Asimetrilerin değerlendirilmesi $(19,29)$,

- DDY hastalarında dudaktaki deformitenin 3 boyutlu olarak değerlendirilmesi, yumuşak doku değişikliklerinin incelenmesi, operasyon öncesi ve sonrasının karşılaştırılması, ilerleyen yaşlarda gelişimin takip edilmesi $(30,37)$,

- Ortognatik cerrahi öncesi ve sonrasında yumușak doku değişimlerinin karşılaștırılması ve ödem tespitinin yapılması için kullanılabilir $(21,30,32,36$, $42,48)$

\section{Stereofotogrametrinin Avantajları}

Stereofotogrametri sistemlerinde kullanılan yüksek teknolojili dijital kameralar sayesinde 1,5 milisaniyede görüntü almak mümkündür. Bu sayede hastanın hareket etmesi sonucu ortaya çıkabilecek olan bozulmalar engellenmekte ve hasta kooperasyonuna olan intiyaç azalmaktadır. Özel bakıma intiyacı olan çocuklar ve DDY'li bebekler gibi kooperasyonun zor olduğu hastalardan doğru ve güvenilir görüntüler alınabilmesi için sistemlerin hızlı çalışması büyük avantaj sağlamaktadır (30).

Stereofotogrametri sistemlerinin radyasyon kullanmayan non-invaziv sistemler olması etik ve hasta açısından avantajlı olduğu gibi sık aralıklarla görüntü alınarak yumuşak dokudaki değişimlerin daha detaylı incelenmesi ve gözlenebilmesi mümkündür (28).

Hastanın stereofotogrametri kayıtları alındığında, materyal randevularında rutin olarak çekilen ekstraoral fotoğrafları da alınmış olur. Fotoğraf çekim süresinin sadece 1,5 milisaniye olduğu düşünüldüğünde daha 
kısa sürede, daha detaylı ve tüm açılardan ekstraoral kayıtları tamamlanmış olur (46).

3 boyutlu stereofotogrametrik görüntülerde anatomik noktaları belirlemek daha kolay ve güvenilirdir. Tedavi öncesi ve sonrası karşılaştırılarak,uygulanan tedavinin yumuşak dokuda meydana getirdiği değişim net bir şekilde değerlendirilebilir (44).

DDY ve travma hastaları gibi yumuşak dokuda deformiteye sahip hastalarda, anomalinin morfolojisini tam olarak yansıtabilmek, hastaların yüzlerindeki asimetrik oluşumların derecelerinin tam olarak belirlenmesi stereofotogrametri sayesinde mümkündür. Operasyon geçiren hastalardan alınan pre-operatif ve post-operatif kayıtların çakıştırılmasıyla da operasyonun planlanan tedaviye ne kadar uygun sonuçlandığı ve yüz morfolojisinde oluşan değişiklikler, stereofotogrametri ile belirlenebilmektedir (39).

Stereofotogrametri ile elde edilen görüntüler STL vb. dosya formatlarında dışa aktarılarak, dijital dental modellerde olduğu gibi başka yerlere gönderilebilir, farklı bilgisayarlarda farklı yazılımlar kullanılarak farklı ölçüm ve analizler uygulanabilir (49).

Çağımızın en hızlı gelişen teknolojileri olan görüntüleme ve bilgisayar sistemleri sayesinde, 3 boyutlu stereofotogrametri sistemlerinin avantajları her geçen gün artmaktadır. Dijital kameralardaki gelişmeler elde edilen görüntülerin çözünürlüklerinin daha yüksek olmasını ve böylece daha detaylı inceleme yapılabilmesini sağlamaktadır. Bilgisayar sistemleri ve yazılım teknolojilerindeki gelişmeler 3 boyutlu görüntü oluşturmayı daha kolaylaştırmakta ve hızlandırmakta, analiz ve ölçümlerden daha kesin sonuçlar alabilmeyi sağlamaktadır. Veri depolama sistemlerinin de gelişimi ve ucuzlaması da daha sık kayıt alınıp, hastada oluşan değişiklikleri daha detaylı inceleme fırsatı sunmaktadır $(43,49-52)$.

\section{Stereofotogrametrinin Dezavantajları}

Stereofotogrametri sistemleriyle ilgili olarak ilk akla gelen dezavantaj standart antropolojik ölçümlere göre bu sistemlerin maliyetinin yüksek olmasıdır. Bu sistemlerin rutin olarak tüm ortodonti kliniklerinde kullanılmamasının en büyük sebebi maliyet-fayda oranının yüksek olmasıdır (32).

Görüntülenmek istenen alana bağlı olarak farklı donanım özelliklerine ve markalara göre değişmekle birlikte genel olarak bu sistemler için büyük bir alana ihtiyaç vardır. Bu yüzden standart muayenehane ve kliniklerde kurulum alanı bulmak neredeyse imkansızdır, fakülte ve araştırma merkezi gibi yerlerde kurulumu mümkün olmaktadır (53).

Çoklu kamera sistemi ile çalışan bu cihazlarda kameraların hassas kalibrasyonu da alınan görüntülerin güvenirliliği için çok önemlidir. Her çekimden sonra üretici firmanın talimatları doğrultusunda kameraların kalibre edilmesi gerekmektedir. Ayrıca sık çekim yapılması gereken yerlerde kalibrasyonun daha hızlı yapılmasına izin veren sistemlerin kurulması gereklidir (53).

Stereofotogrametri sistemlerinde dudaklar arası bölge gibi karanlık; gözler ve kirpik bölgesi gibi gölgeli ve parlak; kulak içi gibi anatomik yapıların fazla girinti çıkıntı gösterdiği bölgelerde görüntü alımında bozulmalar görülebilmektedir. Bu duruma bağlı olarak bu bölgelerden yapılan ölçümlerin güvenirliliği de azalmaktadır (30).

3 boyutlu stereofotogrametri sistemleri sadece yumuşak doku kayıtları için kullanılabilmektedir. Baş ve boyun bölgesinin bütün olarak 3 boyutlu modelini elde edebilmek için sert dokuların, dişlerin ve okluzyonun görüntülenebildiği sistemlerle kombinasyona ihtiyaç vardır (54).

\section{Stereofotogrametri Sistemlerinin Özellikleri}

Stereofotogrametri sistemleri, genel olarak aktif ve pasif sistemler olarak ikiye ayrılırlar.

Aktif sistemler yapısal ışıklandırma yöntemine benzerlik gösterir şekilde nesne üzerinde taranan alana projeksiyon yardımıyla ışık demeti dağıtılır. Rastgele gönderilen ışınların cisim üzerinde oluşturduğu görüntülerden, sistemin kameralarının mümkün olduğunca çok algoritma yakalaması ve bu algoritmaların birleştirilmesiyle de yüksek 
çözünürlüklü 3 boyutlu geometri elde edilir. Bu sistemlerde dışarıdan ekstra bir ışık kaynağına ihtiyaç yoktur ve dışarıdan gelen başka ışıkların da sistem üzerine herhangi bir etkisi bulunmamaktadır $(28,31)$. Pasif sistemlerde ise, herhangi bir ışık kaynağına intiyaç yoktur. Cisimlerin doğal ortam ışığıyla aydınlık ve görülebilir durumda olması bu sistemlerde algılama için yeterlidir ve farklı açılardan elde edilen görüntülerle 3 boyutlu görüntü oluşturulur. Pasif sistemlerde genel olarak hatasız ve güvenilir görüntü elde etmek için yüksek çözünürlüklü dijital kameralara ihtiyaç vardır. Görüntülerde bozulmayı engellemek için ortam ışığının normal seviyelerde olması, taranan cisim yüzeyinde parlama oluşmaması için ışık seviyesinin yüksek olmaması avantaj sağlayacaktır (28).

Her iki sistemde de taranan yüzey bölgesi ve özelliklerine göre değişiklik göstermekle birlikte genel olarak kullanılan donanım bileşenleri şunlardır:

- Kameraları ve flaş ünitelerini taşıyan çerçeve sistemi

- Harici flaş üniteleri

- Modüler kamera üniteleri

- Kalibrasyon kiti

- Güç kaynakları ve bağlantı üniteleri

- Bilgisayar ve donanımlar

- Ayarlanabilir hasta koltuğu.

Modüler kameralar ve bilgisayar, stereofotogrametri sistemlerin temel bileşeni olup kameralar görüntülerin algılanmasını, bilgisayar da yüklenen yazılım sayesinde görüntülerden 3 boyutlu görüntünün oluşturulmasını sağlar. Görüntüleme amacı, alanı ve açısına göre modüler kamera intiyacı da farklılıklar göstermektedir. Stereofotogrametri sistemlerinin en az 2 kameraya ihtiyacı vardır. $160^{\circ}$ ile $360^{\circ}$ arasında değişen görüntüleme açılarına göre kamera sayısı da değişmektedir. $160^{\circ}$ 'lik tarama yapılabilmesi için 2 modül ve 6 kamera kullanırken, $360^{\circ}$ lik taramalarda 5 modül ve 15 kamera ile görüntü sistemleri oluşturulmaktadır (53).

\section{Stereofotogrametride Görüntünün Elde Edilmesi}

3boyutlustereofotogrametrikgörüntününeldeedilmesi, genel olarak 2 aşama şeklinde değerlendirilebilir.
Hastanın cihaza göre pozisyonlandırılıp görüntülerin alınması 1. aşaması iken, alınan görüntülerin bilgisayarda kombinasyonuyla 3 boyutlu hale getirilmesi bu işlemin 2. aşamasıdır (30).

İşlemin 2. aşaması uygun donanım, yazılım, sistem ve teknik kullanıldığında büyük oranda herhangi bir sorunla karşılaşmadan tamamlanabilir. Görüntünün elde edilmesiyle ilgili önemli detaylar ve dikkat edilmesi hastadan görüntülerin alındığı 1. aşama için geçerlidir (53).

İlk olarak hastanın pozisyonlandırılması cihazın kamera açılarına göre ayarlanmalıdır. Cihazın yönlendirmeleri ve merkez kameradan gelen görüntüye göre hastanın pozisyonlandırılması en doğru seçenektir. Konumlandırma sırasında yardımcı personelle çalışılması, bir kişinin ekrandan görüntüyü takip ederken diğer kişinin hastayı pozisyonlandırmasını sağlar. Bu şekilde hem hasta hem de hekim için işlemin kolaylaşması sağlanmış olur. Her ne kadar çekim süresi kısa da olsa hastanın hareketsiz olması net görüntü elde edebilmek için önemlidir. Özellikle $360^{\circ}$ 'lik kraniyal taramalarda sırt desteğinin görüntüye girmemesi de önemlidir. Baş boyun bölgesinden görüntü alımına engel olan giysiler çıkarılmalıdır $(46,53)$.

3 boyutlu stereofotogrametri sistemlerinde doğru görüntü eldeedilebilmesi için kameralarınkalibrasyonu çok önemlidir. Sistemin yönlendirmelerine uygun şekilde sık sık kalibrasyon yapılması görüntü kalitesini arttırmaktadır. Hasta yoğunluğuna bağlı olarak mümkünse her çekimden sonra, mümkün değilse de en azından günde $1 \mathrm{kez}$ sistemin kalibrasyonu yapılmalıdır. Sistemin kullanıldığı bilimsel araştırma durumlarında ise çalışmanın güvenirliliğini arttırmak için her çekimden sonra kalibrasyon yapılması gerekmektedir $(39,53)$.

Yansıma ve distorsiyon sebepleriyle görüntünün yanlış alınmasına sebep olabilecek takı ve aksesuarlar çıkarılmalıdır. 3 boyutlu stereofotogrametri sistemlerinde saçlar net olarak görüntülenememektedir. Bu sebeple hastaya bone taktırmak doğru bir yaklaşım olacaktır. Kulak bölgesi, 
göz bölgesi, çene altı bölge, istirahat durumunda dudakların iç bölgeleri, gülümsemede dudak kenarları gibi ışığın daha az ulaştığı bölgelerde görüntüde bozulma olabilmektedir. Bunları engellemek için çekim esnasında hasta başını biraz geriye yatırmalı, gözlerden de en iyi görüntüyü alabilmek için hastadan gözlerini mümkün olduğunca açık tutmas istenmelidir. Fakat stereofotogrametri sistemlerinde göz yapısının görüntüsünü elde etmek oldukça zordur çünkü gözlerden yansıyan ışık görüntüde bozulmalara sebep olur $(30,36)$.

1. aşama tamamlandıktan sonra görüntüler kontrol edilir ve bilgisayara yüklü yazılımda 3 boyutlu görüntü üretme süreci başlar. Görüntülerin dijital ortamda dış sınırları belirlenerek noktalar kümesine dönüştürülür. Her bir noktanın 3 boyutta da koordinatı belirlenir ve farklı görüntülerden elde edilen noktalar kümeleri birleștirilerek noktalar bulutu (point cloud) olarak adlandırılan yapı elde edilir. Bu noktalar doğru parçalarıyla birleştirilerek üçgenler oluşur ve üçgenlerden de düzlemler elde edilir. Bu şekilde ağ (mesh) denen yapı oluşur ve ne kadar çok nokta olursa o kadar çok üçgen ve buna bağlı olarak o kadar çok düzlem oluşur. Böylece görüntü çözünürlülüğü arttırılarak daha net görüntü elde edilmiş olur. Sistemlerin 2 boyutlu görüntü elde etme tekniği farklı olsa da 3 boyutlu görüntü üreten yazılımların büyük çoğunluğu stereofotogrametride olduğu gibi point cloud, mesh ve 3 boyutlu görüntü aşamalarıyla sonuca ulaşır. Stereofotogrametride, renk ve yüzeyin morfolojik bilgileri de görüntüye eklenir. Elde edilen 3 boyutlu geometrik şekil üzerine bu veriler eklenir ve 3 boyutlu görüntü elde edilmiş olur. 3 boyutlu görüntü genel olarak STL formatında olur ve bu dosya formatı birçok yazılım tarafından açılabilen, yaygın kullanılan bir dosya formatıdır $(28,30,31,36)$.

\section{Üç Boyutlu Stereofotogrametrik Görüntülerde Ölçüm ve Analizler}

Stereofotogrametrik görüntülerde ölçüm ve analizleri 2 gruba ayırabiliriz. Bunlar tek görüntü üzerinde direkt yapılan ölçümler ve iki veya daha fazla görüntünün çakıştırılmasıyla yapılan karşılaşıımalardır.

Tek görüntü üzerinde standart olarak uzunluk ve açısal ölçümler yapmak mümkündür. Bu tip ölçümler genel olarak STL dosyalarını açabilen tüm yazılımlar kullanılarak yapılabilmektedir. Kullanılan sistemin üretici firmasının gönderdiği yazılımlarda da bu tip ölçümler bulunmaktadır. Eğim, kalınlık, deviasyon, hacim gibi ölçümler ise genellikle yazılımlara spesifik ölçümlerdir $(49,52)$.

Diğer analiz ve ölçümler ise farklı görüntülerin çakıştııılması tekniğidir. Ortodontistler tarafından tedavi öncesi, ara safhası ve tedavi bitiminde alınan 2 boyutlu sefalometrik radyografların çakıştırıması rutin yapılan bir işlemdir. Bu ișlemde genellikle belli bir düzlem referans alınarak bu düzlem üzerinde radyograflar çakıştırılır ve oluşan değişimlerin ölçüm ve analizleri yapılır. Aynı mantık 3 boyutlu görüntüler için de geçerliliğini korumuştur. Belirlenen düzlem üzerinde görüntüler çakıştırılır ve 2 görüntü arasındaki değișiklikler gözlemlenebilir. Stereofotogrametri yazılımlarında genellikle görüntü üzerinde otomatik düzlem belirleme ve otomatik çakıştırma özellikleri bulunmaktadır. Çakıştıılan görüntüler arasındaki farkların gösterilmesi amacıyla da cilt rengi ve morfolojik yüzey özellikleri olmadan görüntünün 3 boyutlu geometrik hali kullanılır ve değişimler miktarlarına göre farklı renklerle gösterilerek görsel analiz elde edilmiş olur $(30,49,52,56)$.

\section{Stereofotogrametri Yönteminin Geçerliliği ve Güvenirliliği}

Stereofotogrametri sistemlerinin diğer teknikleri kullanan sistemlere göre büyük avantajlarının bulunması sonucunda bu sisteme olan ilgi artmış ve kullanım alanları genişlemiştir. Ancak bu sistemlerde en önemli kriterlerden biri yapılan ölçüm ve analizlerin doğru, güvenilir ve tekrarlanabilir olmasıdır. Ölçüm ve analizlerin doğruluğu, bu alanda altın standart olarak kabul edilen ölçüm sistemleriyle karşılaştırılması sonucu elde edilen bulgularla uyum ve benzerliğine göre değerlendirilir. Güvenirlilik ise görüntüler üzerinde yapılan ölçüm setleri arasındaki uyum ve tutarlılık olarak değerlendirilebilir. Tekrarlanabilirlik ise aynı model üzerinde aynı yazılım kullanılarak aynı ölçümler yapıldığında sadece kullanıcı hatası veya farkııı̆ı sebebiyle farklı değerler çıkması, onun dışındaki durumlarda aynı sonuçların elde edilmesi 
olarak değerlendirilir $(42,57)$.

3 boyutlu stereofotogrametrik sistemlerinin doğruluk ve güvenirliliği, birçok çalışmada farklı marka ve tipte cihazlar kullanılarak değerlendirilmiştir. Yapılan çalışmalarda 3 boyutlu görüntü elde etme teknikleri ve yöntemler arasındaki farklılıklar, aynı cihazda ölçüm yapan kişiler arasında ve kendi içinde tekrarlanan ölçümlerdeki farklılıklar olarak değerlendirilmiş ve genel olarak $2 \mathrm{~mm}$ 'den daha düşük olarak bulunmuştur ve bu da klinik olarak anlamlı kabul edilmemiştir (49, $52,58,59)$.

\section{Stereofotogrametrinin Diğer 3 Boyutlu Görüntü- leme Teknikleriyle Birlikte Kullanımı}

Stereofotogrametri, yumuşak doku görüntülemede günümüz teknolojisinde en avantajlı yöntem olsa da tek başına tüm verileri sunması mümkün değildir. Stereofotogrametrinin sert dokuları gösterebilme özelliği yoktur ve bu eksikliği ortadan kaldırmak için diş hekimliğinde sert dokuların ayrıntılı şekilde incelenebilmesi amacıyla kullanılan BT ve KIBT'dan elde edilen görüntüler kullanılabilir $(23,60)$.

Stereofotogrametri ve KIBT, yumuşak ve sert doku verilerinin birlikte değerlendirilmesi düşünüldüğünde, birbirlerinin eksiğini kapatan uyumlu ikili gibi görünmektedir. Dişler ve okluzyonun görüntülenmesinde ise iki tekniğinde yetersizlikleri mevcuttur. Tüm maksillofasiyal dokuların doğru görüntülendiği 3 boyutlu modelleme elde edebilmek için KIBT, stereofotogrametri ve dijital dental modellerin kombinasyonunun kullanılması en akılcı yöntem olacaktır. Özellikle ortognatik cerrahi vakalarında olduğu gibi hastanın dış görünüşünde değișiklik yapılacak tedavilerde, bu tekniğin tercih edilmesi doğru teşhis ve tedavi planlaması için gerekli bilgilerin edinilmesini sağlayacaktır $(30,52,60)$.

Cerrahi operasyon ve sert dokularda büyük değişimler planlanmayan ortodonti hastaları için de özellikle istirahat ve gülümseme pozisyonundaki 3 boyutlu görüntülerde diş görünümünün doğru ve güvenilir olabilmesi için yine dijital dental modellerle kombinasyonu gerekmektedir. Yüz estetiğinin belirlenmesinde önemli kriterlerden olan istirahat pozisyonundaki keser görünümü ve doğal gülüş pozisyonundaki gülme hattının doğru belirlenebilmesi için, 3 boyutlu streofotogrametrik tarama ile 3 boyutlu dijital dental modellerin kombinasyonunun kullanımı en doğru yöntemdir $(28,46,60)$.

\section{Sonuç}

İdeal yüz estetiğinin, sosyal ilișkiler ve hayat kalitesi üzerinde ne kadar etkili olduğu bilimsel araştırmalarla kanıtlanmış bir gerçektir $(5,8)$. İdeal yüz estetiğinin sağlanmasında ortodontistler tek başlarına rol almazlar, ancak multidisipliner yaklașım içinde önemli bir role sahiptirler. Bu sebeple ortodontistlerin teșhis ve tedavi planlamasında, yumuşak dokular üzerinde dikkatle durmaları gerekmektedir.

Hastaları her an klinikte görmek mümkün olmadığı için, yumuşak doku incelemelerinde 3 boyutlu görüntüler çok büyük önem arz etmektedir. Bu intiyaca da en iyi cevap verebilen sistem 3 boyutlu stereofotogrametridir $(30,32)$.

Stereofotogrametri, iyonize radyasyon kullanmaması ve ortalama 2,5 milisaniyede görüntü alabilmesi nedeniyle hasta-dostu bir sistem olarak değerlendirilebilir. Hastaya hiçbir zarar vermeden, hastayı uzun süren işlemlerden kurtararak yumuşak dokunun tam olarak doğru ve güvenilir bir şekilde incelenebilmesi, hem hasta hem de hekim açısından oldukça memnuniyet vericidir (28).

3 boyutlu stereofotogrametri sistemlerinin gelişimi ve ucuzlamasıyla birlikte kliniklerde kullanımı da artacaktır. Bu da ortodonti alanında estetik üzerine yapılan çalışmaların ve estetiğin öneminin artmasını sağlayacaktır.

3 boyutlu stereofotogrametrinin sonraki aşaması ise günümüzde henüz yaygınlaşmayan ancak geliştirilmekte olan 4 boyutlu yani statik görüntülerin yanında dinamik (hareketli) 3 boyutlu görüntü alınabilmesini sağlayacak sistemlerdir. Hastanın dinamik kayıtlarının da 3 boyutlu ortama aktarılabilmesi, ortodontik tedavi planlama ve yöntemlerinin gelişimine büyük katkılar sunacaktır. 


\section{Kaynaklar}

1. Ackerman JL, Proffit WR, Sarver DM. The emerging soft tissue paradigm in orthodontic diagnosis and treatment planning. Clin Orthod Res 1999;2:49-52.

2. Spear FM, Kokich VG, Mathews DP. Interdisciplinary management of anterior dental esthetics. JADA 2006;137:160-169.

3. Arnett GW, Gunson MJ. Facial planning for orthodontics and oral surgeons. Am J Orthod Dentofacial Orthop 2004;126:290-5.

4. Primozic J, Perinetti G, Richmond S, Ovsenik M. Threedimensional evaluation of facial asymmetry in association with unilateral functional crossbite in the primary, early, and late mixed dentition phases. Angle Orthod 2013;83:253-258.

5. Shaw WC. The influence of children's dentofacial appearance on their social attractiveness as judged by peers and lay adults. Am J Orthod 1981;79:399415.

6. Peck S, Peck L. Facial realities and oral esthetics. In: McNamara JA Jr, editor. Esthetics and the treatment of facial form. Craniofacial Growth Series, Volume 28. Ann Arbor: Center for Human Growth and Development; University of Michigan,1993;77-113.

7. Kerosuo $H$, Hausen $H$, Laine $T$, Shaw WC. The influence of incisal malocclusion on the social attractiveness of young adults in Finland. Eur $\mathrm{J}$ Orthod 1995;17(6):505-512.

8. Rhodes $G$. The evolutionary psychology of facial beauty. Annu Rev Psychol 2006;57:199-226.

9. Kiyak HA. Cultural and psychologic in uences on treatment demand. Semin in Orthod 2000;6:242-248. 10. Elif F. Erbay, DDS, MS, PhD,a and Cem M. Canikliog lu, DDS, PhDb. Soft tissue profile in Anatolian Turkish adults: Part II. Comparison of different soft tissue analyses in the evaluation of beauty. Am J Orthod Dentofacial Orthop 2002;121:65-72.

11. Ricketts RM. Planning treatment on the basis of the facial pattern and an estimate of its growth. Angle Orthod 1957;27:14-37.

12.Steiner CC. The use of cephalometrics as an aid to planning and assessing orthodontic treatment. Am J Orthod 1960;46:721-35.

13. Merrifield LL. The profile line as an aid in critically evaluating facial esthetics. Am J Orthod 1966;52:804-22.
14.Burstone CJ. Lip posture and its significance in treatment planning. Am J Orthod 1967;53:262-84.

15. Sushner NI. A photographic study of the softtissue profile of the Negro population. Am J Orthod 1977;72:373-85.

16. Holdaway RA. A soft tissue cephalometric analysis and its use in orthodontic treatment planning. Part I. Am J Orthod 1983;84:1-28.

17.Farkas LG, Posnick JC, Hreczko TM. Anthropometric growth study of the head. Cleft Palate Craniofac J 1992;29:303-308.

18.Wong JY, Oh AK, Ohta E, et al. Validity and reliability of craniofacial anthropometric measurement of $3 \mathrm{D}$ digital photogrammetric images. Cleft Palate Craniofac J 2008;45:232-239.

19. Edler R, Wertheim D, Greenhill D. Comparison of radiographic and photographic measurement of mandibular asymmetry. Am J Orthod Dentofacial Orthop 2003;123:167-174.

20.Khambaya B, Nairn N, Bell A, Miller J, Bowmanb A, Ayoub AF. Validation and reproducibility of a highresolution three-dimensional facial imaging system. Br J Oral Maxillofac Surg 2008;46:27-32.

21.Plooij JM, Maal TJJ, Haers P, Borstlap WA, Kuijpers-Jagtman AM, Berge' SJ: Digital threedimensional image fusion processes for planning and evaluating orthodontics and orthognathic surgery. A systematic review. Int Oral Maxillofac Surg 2011:40:341-352.

22. Littlefield TR, Kelly KM, Cherney JC, Beals SP, Pomatto JK. Development of a new threedimensional cranial imaging system. J Craniofac Surg 2004;15:175-181.

23.Scarfe WC, Farman AG, Sukovic P. Clinical applications of cone beam computed tomography in dental practice. J Can Dent Assoc 2006;72:75 80.

24.Vig PS. Orthodontic controversies: Their origins, consequences and resolution. In: Current Controversies in Orthodontics. Chicago, Quintessence Publishing 1991; 269310.

25. Mckee IW, Williamson PC, Lam EW, Heo G, Glover $\mathrm{KE}$, Major PW. The accuracy of 4 panoramic units in the projection of mesiodistal tooth angulations. Am J Orthod Dentofacial Orthop 2002;121:166 75.

26. Hell B. 3D sonography. Int Oral Maxillofac Surg 1995;24:84-9.

27. Sadar R, Zeilhofer HF, Horch HH. Diagnostic 
possibilities of three-dimensional imaging of ultrasound image data in mouth, jaws and facial surgery. Biomed Technol 1997;42:211-212.

28. Tzou CHJ, Frey M. Evolution of 3D Surface Imaging Systems in Facial Plastic Surgery. Facial Plast Surg Clin N Am 2011;19:591-602.

29. Ras F, Habets L, van Ginkel FC, Prahl-Andersen B. Method for quantifying facial asymmetry in three dimensions using stereophotogrammetry. Angle Orthod 1995;65(3):233-239.

30.Görgülü S, Duran GS, Dindaroğlu F. Güncel Bilgiler Işığında Ortodonti (1.Baskı), Erhan Özdiler, Gümüș Kitabevi, Ankara, 2015:367-381.

31. Kau CH, Richmond S, Zhurov A, Ovsenik M, Tawfik W, Borbely P, English JD. Use of 3-dimensional surface acquisition to study facial morphology in 5 populations. Am J Orthod Dentofacial Orthop 2010;137:S56.e1-S56.e9.

32.Karataş $\mathrm{OH}$, Toy $\mathrm{E}$. Three dimensional imaging techniques: A literature review. Eur J Dent 2014;8(1):1-9. 33.Thalmaan D. Die Stereogrammetrie: ein diagnostisches Hilfsmittelinder Kieferorthopaedie [Stereophotogrammetry: a diagnostic device in orthodontology]. Zurich (Switzerland): University Zurich, Switzerland; 1944 [German].

34.Burke $\mathrm{PH}$, Beard FH. Stereophotogrammetry of the face. A preliminary investigation into the accuracy of a simplified system evolved for contour mapping by photography. Am J Orthod 1967;53(10):769-82.

35. Deacon AT, Anthony AG, Bhatia SN, Muller JP. Evaluation of a CCD-based facial measurement system. Int J Med Inform 1991;16(2):213-28.

36. Ayoub AF, Siebert P, Moos KF, Wray D, Urquhart C, Niblett TB. A vision-based three-dimensional capture system for maxillofacial assessment and surgical planning. Br J Oral Maxillofac Surg 1998;36:353-7. 37. Hajeer MY, Mao Z, Millett DT, Ayoub AF, Siebert JP. A new three-dimensional method of assessing facial volumetric changes after orthognathic treatment. Cleft Palate Craniofac J 2005;42:113-20.

38. Buckley PF, Dean D, Bookstein FL, et al. A three dimensional morphometric study of craniofacial shape in schizophrenia. Am J Psychiatry 2005;162:606-8.

39.Winder RJ, Darvann TA, McKnightc W, Mageed JDM, Ramsay-Baggs P. Technical validation of the Di3D stereophotogrammetry surface imaging system. Br J Oral Maxillofac Surg 2008;46:33-37.
40.Gor T, Kau CH, English JD, Lee RP, Borbely P. Three-dimensional comparison of facial morphology in white populations in Budapest, Hungary, and Houston, Texas. Am J Orthod Dentofacial Orthop 2010;137:424-32.

41. Tanikawa C, Zere E, Takada K. Sexual dimorphism in the facial morphology of adult humans: A threedimensional analysis. J Comp Hum Biol 2015;1:94-3. 42. Kau CH, Kamel SG, Wilson J, Wong ME. New method for analysis of facial growth in a pediatric reconstructed mandible. Am J Orthod Dentofacial Orthop 2011;139(4): e285-290.

43. vander Meera WJ, Dijkstra PU, Visser A, Vissink A, Rene Y. Reliability and validity of measurements of facial swelling with astereo photogrammetry optical three-dimensional scanner. Br J Oral Maxillofac Surg 2014;52:922-927.

44.Weinberg SM, Kolar JC. Three-dimensional surface imaging: limitations and considerations from the anthropometric perspective. J Craniofac Surg 2005;16:847-851.

45.Rosati R, De Menezes M, Rossetti A, et al. Digital dental cast placement in 3-dimensional, full-face reconstruction: a technical evaluation. Am J Orthod Dentofacial Orthop 2010;138(1):84-8.

46. Maal TJ, van Loon B, Plooij JM, et al. Registration of 3-dimensional facial photographs for clinical use. J Oral Maxillofac Surg 2010;68(10):2391-401.

47. Fourie Z, Damstra J, Gerrits PO, et al. Evaluation of anthropometric accuracy and reliability using different three-dimensional scanning systems. Forensic Sci Int 2011;207(1-3):127-34.

48. Chung How Kau, Stephen Richmond, Angela Incrapera, Jeryl English, James Jiong Xia. Threedimensional surface acquisition systems for the study of facial morphology and their application to maxillofacial surgery. . Int $\mathrm{J}$ Med Robotics Comput Assist Surg 2007;3:97-110.

49.de Menezes M, Rosati R, Ferrario VF, et al. Accuracy and reproducibility of a 3-dimensional stereophotogrammetric imaging system. J Oral Maxillofac Surg 2010;68(9):2129-35.

50. Kochel J, Meyer-Marcotty P, Strnad F, Kochel M, Stellzig-Eisenhauer A. 3D soft tissue analysis-part 1: sagittal parameters. J Orofac Orthop 2010;71:40-52. 51.Brons S, van Beusichem ME, Bronkhorst EM. Methods to quantify soft-tissue based facial growth 
and treatment outcomes in children: a systematic review. PLoS One. 2012;7:e41898.

52.Plooij JM, Swennen GRJ, Rangel FA, Maal TJJ, Schutyser FAC, Bronkhorst EM, KuijpersJagtman AM, Berge SJ. Evaluation of reproducibility and reliability of 3D soft tissue analysis using 3D stereophotogrammetry. Int Oral Maxillofac Surg 2009;38:267-273.

53. Heike CL, Upson K, Stuhaug E, Weinberg SM. 3D digital stereophotogrammetry: a practical guide to facial image acquisition. Head Face Med 2010;28:6-18. 54.Rangel FA, Maal TJJ, Berge' SJ, et al. Integration of digital dental casts in 3-dimensional facial photographs. Am J Orthod Dentofacial Orthop 2008;134:820-826.

55.Chung How Kau, Stephen Richmond, Angela Incrapera, Jeryl English, James Jiong Xia. Threedimensional surface acquisition systems for the study of facial morphology and their application to maxillofacial surgery. Int J Med Robotics Comput Assist Surg 2007;3(2):97-110.

56. Khambaya B, Ullah R. Current methods of assessing the accuracy of threedimensional soft tissue facial predictions: technical and clinical considerations. Int J Oral Maxillofac Surg 2015; 44: 132-138.

57. Metzger MC, Hohlweg-Majert B, Scho"n R, Teschner M, Gellrich NC, Schmelzeisen R. Verification of clinical precision after computeraided reconstruction in craniomaxillofacial surgery. Oral Surg Oral Med Oral Pathol Oral Radiol Endod 2007;104: 1-10.

58. Catherwood T, McCaughan E, Greer E, Spence RAJ, Mclntosh SA, Windera RJ. Validation of a passive stereophotogrammetry system for imaging of the breast: A geometric analysis. Med Eng Phys 2011;33:900-905.

59.van Loon B, van Heerbeek N, Maal TJ, Borstlap WA, Ingels KJ, et al. Postoperative volume increase of facial soft tissue after percutaneous versus endonasal osteotomy technique in rhinoplasty using 3D stereophotogrammetry. Rhinology 2011;49(1):121126.

60.Naudi KB, Benramadan R, Brocklebank L, Ju X, Khambay B, Ayoub A. The virtual human face: superimposing the simultaneously captured 3D photorealistic skin surface of the face on the untextured skin image of the CBCT scan. Int $\mathrm{J}$ Oral Maxillofac Surg 2013;42:393-400. 